\title{
IMPORTANCE OF KARST SINKHOLES IN PRESERVING RELICT, MOUNTAIN, AND WET-WOODLAND PLANT SPECIES UNDER SUB-MEDITERRANEAN CLIMATE: A CASE STUDY FROM SOUTHERN HUNGARY
}

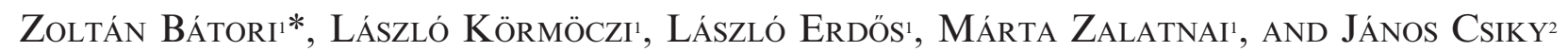

\begin{abstract}
Species composition and the vegetation pattern of the understory were investigated in different sized solution sinkholes in a woodland area of the Mecsek Mountains (southern Hungary). Vegetation data together with topographic variables were collected along transects to reveal the vegetation patterns on the slopes, and a species list was compiled for each sinkhole. The results indicate that the vegetation pattern significantly correlates with sinkhole size. In smaller sinkholes, vegetation does not change substantially along the transects; in larger sinkholes, however, vegetation inversion is pronounced. We also found that sinkhole size clearly influences the number of vascular plant species, in accordance with the well-known relationship between species number and area. In the forest landscape, many medium-sized and large sinkholes have developed into excellent refuge areas for glacial relicts, mountain, and wet-woodland plant species.
\end{abstract}

\section{INTRODUCTION}

Climate-induced species extinction has become a major topic in conservation biology. Articles and books focusing on climate change have appeared (e.g., Iverson and Prasad, 1998; Sagarin et al., 1999; Cowie, 2007), and a rapidly increasing amount of information is available about current and potential refuge areas (e.g., Köhn and Waterstraat, 1990; Schindler et al., 1996; Sheldon et al., 2008) where many species may survive unfavorable regional environmental conditions. During glacial periods, a major part of Europe was largely covered by cold habitats, and only cold-adapted species were able to survive under these extreme conditions (Habel et al., 2010). However, after glacial retreat, sites with cold and humid climates became important to preserving glacial relicts and high mountain and mountain species, mainly in lower mountain and hill ranges.

On a global scale, extensive karst limestone bedrock plays an important role in the preservation of rare, endangered, or specialized species (e.g., Christiansen and Bellinger, 1996; Wolowski, 2003; Judson, 2007; Lewis and Bowman, 2010). Karst landforms like caves, wells and sinkholes (also known as dolines) determine the geomorphologic, microclimatic, and vegetation features of karst surfaces and influence the karst aquifer system. Moreover, caves and wells are hotspots of subterranean biodiversity (Culver and Sket, 2000; Elliott, 2007); sinkholes preserve relicts (Horvat, 1953; Lazarević et al., 2009), high mountain, mountain, (Beck v. Mannagetta, 1906; Horvat, 1953; Pericin and Hürlimann, 2001; Dakskobler et al., 2008) and endemic (Egli et al., 1990; Brullo and Giusso del Galdo, 2001; Özkan et al., 2010) species, and, in many cases, they are an important source of knowledge about vegetation history. For example, Dracocephalum ruyschiana, a glacial relict in the sinkhole flora of northern Hungary, indicates a former periglacial climate (Király, 2009), but some high mountain elements (e.g. Lilium martagon subsp. alpinum, Ribes alpinum) also occur in the low-lying sinkholes (between 400 and 600 masl) of the area (Szmorad, 1999; Vojtkó, 1997).

Understanding the patterns of sinkhole vegetation requires an understanding of the surrounding vegetation patterns. According to Horvat (1953), the cool and humid microclimate of sinkholes may affect their flora and vegetation in two different ways. In many cases, thermal inversion leads to an inversion of surrounding vegetation zones. On the other hand, edaphic vegetation types may also appear on the bottom of sinkholes under special ecological conditions (Egli, 1991; Bátori et al., 2009). From an ecological point of view, the latter is more important, as it may provide primary habitats for many species absent in the surrounding vegetation.

The purpose of the present study is to determine and compare the vegetation pattern and species composition in solution sinkholes of the sub-Mediterranean part of Hungary with regard to sinkhole size and to offer some useful explanations for their role in nature conservation. The following questions are addressed: (i) What is the extent of vegetation inversion in different-sized sinkholes in a woodland area? (ii) How does the extent of refuge areas change with sinkhole size? (iii) How many relict, mountain,

\footnotetext{
* Corresponding author: zbatory@gmail.com

${ }^{1}$ Department of Ecology, University of Szeged, 6726 Szeged, Közép fasor 52, Hungary

${ }^{2}$ Department of Plant Taxonomy and Geobotany, University of Pécs, 7624 Pécs, Ifjúság útja 6, Hungary
} 

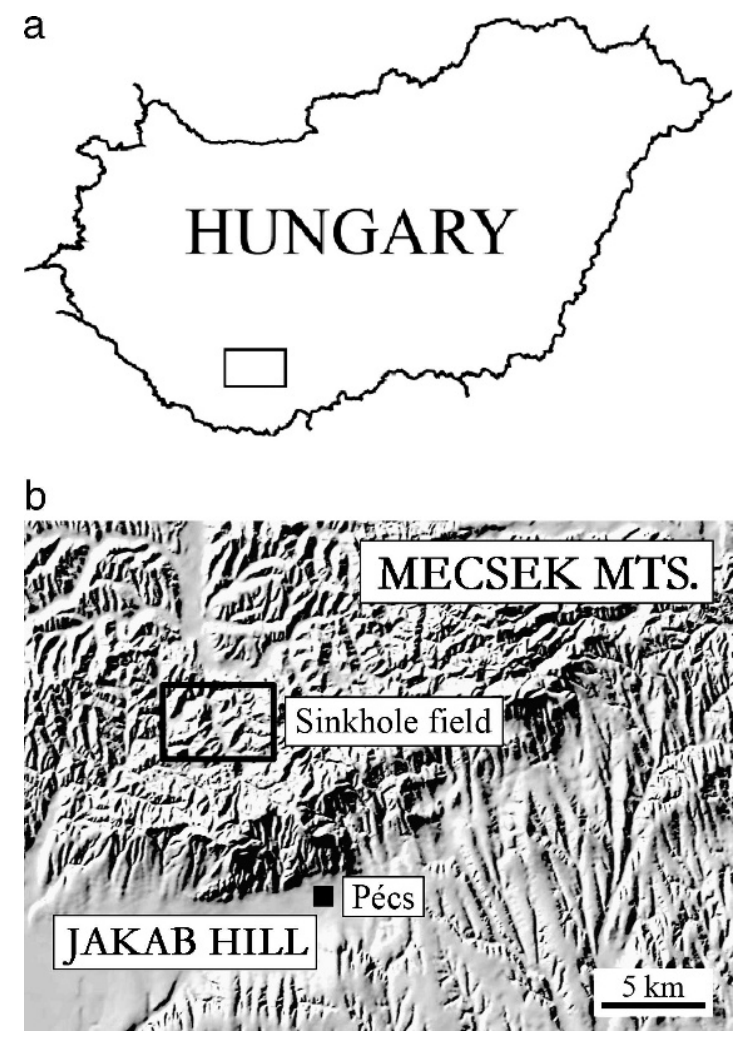

Figure 1. Location of the study site in the Mecsek Mountains (southern Hungary).

and wet-woodland plant species can be found in the different sized sinkholes?

\section{Methods}

The study was carried out in the karst area of $30 \mathrm{~km}^{2}$ in the Mecsek Mountains (southern Hungary), near the city of Pécs (Fig. 1). On the karst surface, there are more than two thousand sinkholes located between 250 and $500 \mathrm{~m}$ above sea level (Fig. 2). The formation of these depressions started during the Pleistocene, and it is still intensive due to the abundant precipitation on the fissured bedrock underlying the woodland. The diameter of the largest sinkhole is over $200 \mathrm{~m}$ and its depth exceeds $30 \mathrm{~m}$ (Lovász, 1971), but more than fifteen hundred of these sinkholes are quite small (diameter $<20 \mathrm{~m}$ ). The sinkhole density of this area is extremely high, with the maximum of 380 sinkholes per $\mathrm{km}^{2}$. These depressions are in primitive stages of development, shown by their steep slopes and a funnel-like form (Hoyk, 1999).

The average annual rainfall of the study site exceeds $700 \mathrm{~mm}$, with considerable interannual variation. Due to the sub-Mediterranean climate, the monthly maximum values occur during summer and autumn (May and June $77 \mathrm{~mm}$, October $72 \mathrm{~mm}$ ). The annual mean temperature is about $8.8{ }^{\circ} \mathrm{C}$, with the highest monthly mean temperature of $19.3{ }^{\circ} \mathrm{C}$ in July. Winters are moderately cold with $-1.1{ }^{\circ} \mathrm{C}$

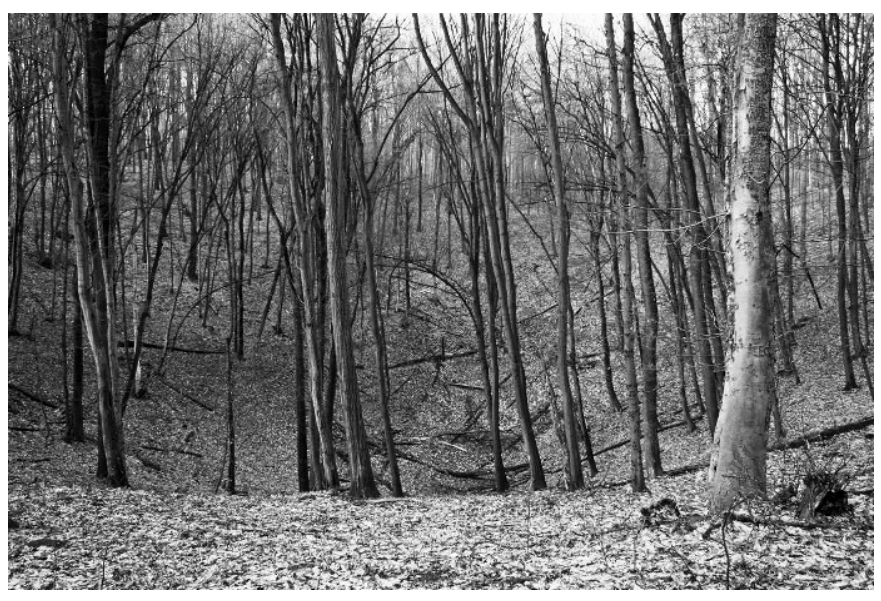

Figure 2. A large solution sinkhole (sinkhole $O$ ) of the Mecsek Mountains in the winter of 2008.

mean temperature from December to February (Ádám et al., 1981).

Sub-Mediterranean type, middle-aged (70 to 110 years old) mixed-oak and beech forests dominate the present vegetation of the plateaus and slopes of the study site. The most important Atlantic-Mediterranean, sub-Mediterranean, and Mediterranean plants include Aremonia agrimonoides, Asperula taurina, Helleborus odorus, Lathyrus venetus, Luzula forsteri, Potentilla micrantha, Rosa arvensis, Ruscus aculeatus, Ruscus hypoglossum, Scutellaria altissima, Tamus communis, and Tilia tomentosa. Hotspots of mountain species of the area can be found in the forests of the deep, humid, and rocky ravines and valleys.

Our surveys were conducted between 2006 and 2011 from early June to mid-September on the karst surface of the Mecsek Mountains. Sinkholes were selected in sites that did not show signs of recent wood-cutting. Sinkholes ranked by diameter are identified with capital letters from A to $\mathrm{T}$ (Table 1).

Transects for sampling understory were established across the twenty sinkholes in a north-south direction, passing through the deepest point of the depressions. Transects consisted of series of $1 \mathrm{~m}$ square contiguous plots. In the larger sinkholes, the transects were $2 \mathrm{~m}$ wide, with individual plots side-by-side along them. In the smaller sinkholes, only a $1 \mathrm{~m}$ wide series was surveyed. Percentage cover of each vascular plant species was estimated visually in the plots. Furthermore, a flora list for each sinkhole was completed by a systematic search through the total area of the sinkhole. The total area included the area of the slopes (where the slope angle was over $10^{\circ}$ ) and the area of the edges, an approximately 1 to $5 \mathrm{~m}$ wide strip around the smaller sinkholes, and an approximately 10 to $20 \mathrm{~m}$ wide strip around the larger sinkholes where the slope angle was less than $10^{\circ}$. For comparison, $4051 \mathrm{~m}$ square plots were randomly taken from the three habitat types, mixed-oak forests, beech 
Table 1. Diameters and depths of the studied sinkholes of the Mecsek Mountains.

\begin{tabular}{lcrrrrrrrrrrrrrrrrrrr}
\hline Sinkhole & & & & & & & & & & & & & & & & & & & & \\
Dimensions, & A & B & C & D & E & F & G & H & I & J & K & L & M & N & O & P & Q & R & S & T \\
\hline Diameter & 9.5 & 14.5 & 15 & 18 & 21 & 23 & 43 & 60 & 69 & 76 & 81 & 85 & 92 & 124 & 135 & 145 & 158 & 167 & 187 & 229 \\
Depth & 1 & 2.5 & 2.5 & 3 & 4.5 & 3.5 & 7 & 12 & 12 & 12 & 15 & 15 & 13 & 17 & 19 & 25 & 22 & 22 & 21 & 31 \\
\hline
\end{tabular}

forests, and forests in the deep ravines and valleys (called ravine forests below), occurring in the neighborhood of the sinkholes. We studied a total of 4017 plots on the karst of Mecsek Mountains: 3612 plots in sinkholes and 405 plots in their surroundings. A total of 251 vascular plant species were included in the analyses. In addition, the diameter and depth of the sinkholes were measured (Table 1). Plant species were named according to Simon (2000).

Diagnostic (or differential) species include species with high occurrence within a given vegetation type (or within some vegetation types) and low occurrence in other vegetation types. Diagnostic species of the different forest types surrounding the sinkholes were determined by statistical fidelity measures (Chytrý et al., 2002). The phi coefficient $(\Phi)$ for all species was computed with the JUICE 7.0.25 program (Tichý, 2002). This coefficient ranges from -1 to 1 , but for convenience, it is multiplied by 100 in the program. The highest phi value of 1 is achieved if the species occurs in all plots of the target vegetation type and is absent elsewhere. For the comparison of mixed-oak forests, beech forests, and ravine forests (405 total plots), we used the $\Phi \geq 0.1$ threshold (Fisher's exact test, $p<0.05$ ) during analyses. The classified data set contained only site groups of equal size (135 plots for each group). In this scale, fidelity measurement resulted in three groups of diagnostic species in the understories of the mixed-oak forests, the beech forests, and the ravine forests (Table 2). Finally, we classified each $1 \mathrm{~m}$ square plot along the sinkhole transects into plot types with the use of the diagnostic species groups. For example, if the number of diagnostic species of the ravine forests was the highest in the target sinkhole plot, we considered it a plot dominated by ravine forest species. Hence, this method resulted in five sinkhole-plot types: plots dominated by ravine forest species, plots dominated by beech forest species, plots dominated by mixed-oak forest species, transitional plots, and empty plots. Transitional plots were those which were dominated by an equal number of diagnostic species of two or three groups. Empty plots did not contain any plant species. From an ecological point of view, plots dominated by ravine forest species can be considered potential refuge areas for many species adapted to cool and moist habitats (e.g., Fig. 3). Moreover, field observations were performed to verify the result of fidelity measurement.

Species-area relations were assessed for all plant species, as well as for the group of relict, mountain, wet-woodland species and other diagnostic species of the ravine forests. In this study, twenty sinkholes, representative of sinkholes of all sizes, were included in the species-area analyses.

\section{RESUlts}

The number of $1 \mathrm{~m}$ square plots dominated by ravine forest species generally increased with sinkhole size (Fig. 4; Table 3). In the small and shallow sinkholes A to G, only plots dominated by beech forest and mixed-oak forest species were found. In contrast, in larger sinkholes, the lower parts of the slopes were covered mainly by plots dominated by ravine forest species; while the upper parts of the slopes were covered by plots dominated by beech forest or mixed-oak forest species. In some sinkholes, the proportion of mixed-oak forest species was very high on the edges and south-facing slopes. Accordingly, vegetation inversion was pronounced, especially in the case of sinkholes $\mathrm{N}, \mathrm{S}, \mathrm{Q}$, and $\mathrm{T}$, followed by a gradual change in floristic composition.

Of the forty-one diagnostic species of the ravine forests found, five were mountain species, ten were wet-woodland species, and twenty-six were other diagnostic species (e.g., gap-species) (Table 2). In addition, a glacial relict (Stachys alpina), six other mountain species (Actaea spicata, Aruncus sylvestris, Dryopteris affinis, Dryopteris dilatata, Dryopteris expansa, and Polystichum $\times$ bicknelli), and six other wetwoodland species (Deschampsia caespitosa, Eupatorium cannabinum, Festuca gigantea, Lycopus europaeus, Rumex sanguineus, and Solanum dulcamara) were found in the ravine forests, although they were not diagnostic according to the test.

The relationship between sinkhole size ( $\log _{10}$ transformed) and species number $\left(\log _{10}\right.$ transformed) is shown in Fig. 5. When all species were considered, the correlation between species number and sinkhole size was positive and significant $\left(R^{2}=0.9302, p<0.001\right)$. For example, the highest number of species (141) was found in the largest sinkhole $(\mathrm{T})$, while the lowest number of species (23) was found in two of the smallest sinkholes (A and C) (Table 3). The result was basically the same if only the group of relict, mountain, wet-woodland species and other diagnostic species of the ravine forests was considered $\left(R^{2}=0.9006, p<0.001\right)$. From a floristic point of view, sinkholes $R$ and $T$ were the most important, because they contained the highest number of both relicts and mountain species (R: Dryopteris affinis, Dryopteris expansa, Dryopteris dilatata, Polystichum aculeatum, Polystichum $\times$ bicknelli and Stachys alpina; T: Aconitum vulparia, Actaea spicata, Asplenium scolopendrium, Dryopteris affinis, Polystichum aculeatum, Polystichum $\times$ bicknelli and Stachys alpina). 
Table 2. Diagnostic species of the types of forest surrounding sinkholes in the Mecsek Mountains, defined by $\Phi \times 100 \geq$ 10. If a species is in the list for more than one forest type, its $\Phi$ value is shown in both parts of the table.

\begin{tabular}{|c|c|c|c|}
\hline \multirow[b]{2}{*}{ Vegetation Type and Species } & \multicolumn{3}{|c|}{$\Phi \times 100$} \\
\hline & MOF & $\mathrm{BF}$ & $\mathrm{RF}$ \\
\hline \multicolumn{4}{|c|}{ Diagnostic species of the mixed-oak forests } \\
\hline Lathyrus vernus & 10.3 & 21.5 & $\ldots$ \\
\hline Festuca drymeja & 11.1 & $\cdots$ & $\ldots$ \\
\hline Melittis carpatica & 11.1 & $\cdots$ & $\cdots$ \\
\hline Galium mollugo & 12.2 & $\cdots$ & $\cdots$ \\
\hline Poa nemoralis & 12.2 & $\cdots$ & $\cdots$ \\
\hline Moehringia trinervia & 12.9 & $\cdots$ & $\cdots$ \\
\hline Campanula persicifolia & 14.1 & $\cdots$ & $\cdots$ \\
\hline Carex divulsa & 14.1 & $\ldots$ & $\ldots$ \\
\hline Symphytum tuberosum & 14.1 & $\ldots$ & $\ldots$ \\
\hline Torilis japonica & 14.1 & $\ldots$ & $\ldots$ \\
\hline Brachypodium sylvaticum & 14.2 & $\ldots$ & $\ldots$ \\
\hline Sorbus torminalis & 14.2 & $\ldots$ & $\ldots$ \\
\hline Galium aparine & 15.8 & $\ldots$ & $\ldots$ \\
\hline Luzula forsteri & 15.8 & $\ldots$ & $\ldots$ \\
\hline Prunella vulgaris & 15.8 & $\ldots$ & $\ldots$ \\
\hline Alliaria petiolata & 16.2 & $\ldots$ & $\ldots$ \\
\hline Ruscus aculeatus & 16.3 & $\ldots$ & $\ldots$ \\
\hline Carex pilosa & 16.4 & 51.1 & $\ldots$ \\
\hline Quercus petraea & 18.4 & 14.2 & $\ldots$ \\
\hline Potentilla micrantha & 20.1 & $\cdots$ & $\ldots$ \\
\hline Viola alba & 20.1 & $\ldots$ & $\ldots$ \\
\hline Viola odorata & 20.1 & $\ldots$ & $\ldots$ \\
\hline Buglossoides purpureo- & & & \\
\hline coerulea & 22.5 & $\ldots$ & $\ldots$ \\
\hline Lysimachia nummularia & 22.5 & $\cdots$ & $\ldots$ \\
\hline Veronica chamaedrys & 23.3 & $\cdots$ & $\ldots$ \\
\hline Tamus communis & 23.6 & $\ldots$ & $\ldots$ \\
\hline Festuca heterophylla & 24.7 & $\ldots$ & $\ldots$ \\
\hline Fragaria vesca & 26.4 & $\ldots$ & $\ldots$ \\
\hline Galium schultesii & 26.8 & $\ldots$ & $\ldots$ \\
\hline Geum urbanum & 29.1 & $\ldots$ & $\ldots$ \\
\hline Campanula rapunculoides & 30.5 & $\ldots$ & $\ldots$ \\
\hline Crataegus laevigata & 30.6 & $\ldots$ & $\ldots$ \\
\hline Acer campestre & 30.8 & $\ldots$ & $\ldots$ \\
\hline Carpinus betulus & 31.3 & $\ldots$ & $\ldots$ \\
\hline Helleborus odorus & 33.3 & $\ldots$ & $\ldots$ \\
\hline Quercus cerris & 34.4 & $\ldots$ & $\ldots$ \\
\hline Convallaria majalis & 34.7 & $\ldots$ & $\ldots$ \\
\hline Euphorbia amygdaloides & 35.0 & $\ldots$ & $\ldots$ \\
\hline Fallopia dumetorum & 39.3 & $\ldots$ & $\ldots$ \\
\hline Euonymus verrucosus & 40.0 & $\ldots$ & $\ldots$ \\
\hline Bromus ramosus agg. & 43.5 & $\ldots$ & $\ldots$ \\
\hline Melica uniflora & 45.1 & 39.8 & $\ldots$ \\
\hline Rosa arvensis & 45.3 & $\ldots$ & $\ldots$ \\
\hline Glechoma hirsuta & 54.9 & $\ldots$ & $\ldots$ \\
\hline Ligustrum vulgare & 56.9 & $\ldots$ & $\ldots$ \\
\hline Stellaria holostea & 60.6 & $\ldots$ & $\ldots$ \\
\hline
\end{tabular}

Table 2. Continued.

\begin{tabular}{lrrr}
\hline & \multicolumn{3}{c}{$\Phi \times 100$} \\
\cline { 2 - 4 } Vegetation Type and Species & MOF & BF & RF \\
\hline Fraxinus ornus & 66.4 & $\ldots$ & $\ldots$ \\
Dactylis polygama & 72.9 & $\ldots$ & $\ldots$
\end{tabular}

Diagnostic species of the beech forests

Ulmus glabra
Milium effusum
Quercus petraea
Galeobdolon luteum s.1.
Asarum europaeum
Viola reichenbachiana
Carex digitata
Hepatica nobilis
Lathyrus vernus
Ruscus hypoglossu
Prunus avium
Tilia tomentosa
Tilia cordata
Rubus hirtus agg.
Fraxinus excelsior
Melica uniflora
Hedera helix
Fagus sylvatica
Carex pilosa
Galium odoratum

$\begin{array}{lll}\ldots & 12.4 & \ldots \\ \ldots & 14.1 & \ldots \\ 18.4 & 14.2 & \ldots \\ \ldots & 14.7 & 59.8 \\ \ldots & 15.1 & \ldots \\ \ldots & 15.1 & \ldots \\ \ldots & 16.3 & \ldots \\ \ldots & 20.9 & \ldots \\ 10.3 & 21.5 & \ldots \\ \ldots & 21.8 & \ldots \\ \ldots & 24.7 & \ldots \\ \ldots & 25.6 & \ldots \\ \ldots & 31.4 & \ldots \\ \ldots & 32.4 & \ldots \\ \ldots & 32.6 & \ldots \\ 45.1 & 39.8 & \ldots \\ \ldots & 43.5 & \ldots \\ \ldots & 49.2 & \ldots \\ 16.1 & 51.1 & \ldots \\ \ldots & 53.9 & \ldots\end{array}$

Diagnostic species of the ravine forests

Mountain species

$\begin{array}{llll}\text { Polystichum aculeatum } & \ldots & \ldots & 22.5 \\ \text { Aconitum vulparia } & \ldots & \ldots & 26.8 \\ \text { Lunaria rediviva } & \ldots & \ldots & 27.7 \\ \text { Silene dioica } & \ldots & \ldots & 30.5 \\ \text { Asplenium scolopendrium } & \ldots & \ldots & 37.8 \\ \text { Wet woodland species } & & & \\ \text { Dryopteris carthusiana } & \ldots & \ldots & 15.8 \\ \text { Myosoton aquaticum } & \ldots & \ldots & 15.8 \\ \text { Persicaria dubia } & \ldots & \ldots & 15.8 \\ \text { Carex pendula } & \ldots & \ldots & 17.3 \\ \text { Ranunculus repens } & \ldots & \ldots & 25.8 \\ \text { Carex remota } & \ldots & \ldots & 27.7 \\ \text { Urtica dioica } & \ldots & \ldots & 42.8 \\ \text { Aegopodium podagraria } & \ldots & \ldots & 44.8 \\ \text { Athyrium filix-femina } & \ldots & \ldots & 46.2 \\ \text { Chrysosplenium } & & & \\ \text { alternifolium } & \ldots & \ldots & 64.9\end{array}$

Other diagnostic species of the ravine forests

$\begin{array}{llll}\text { Mercurialis perennis } & \ldots & \ldots & 11.1 \\ \text { Galeopsis speciosa } & \ldots & \ldots & 12.2 \\ \text { Erigeron annuus } & \ldots & \ldots & 12.2 \\ \text { Pulmonaria officinalis } & \ldots & \ldots & 12.4 \\ \text { Cerastium sylvaticum } & \ldots & \ldots & 14.1 \\ \text { Knautia drymeia } & \ldots & \ldots & 14.1\end{array}$


Table 2. Continued.

\begin{tabular}{lccc}
\hline & \multicolumn{3}{c}{$\Phi \times 100$} \\
\cline { 2 - 4 } Vegetation Type and Species & MOF & BF & RF \\
\hline Atropa bella-donna & $\ldots$ & $\ldots$ & 15.8 \\
Salvia glutinosa & $\ldots$ & $\ldots$ & 15.8 \\
Clematis vitalba & $\ldots$ & $\ldots$ & 16.3 \\
Lamium maculatum & $\ldots$ & $\ldots$ & 16.6 \\
Chelidonium majus & $\ldots$ & $\ldots$ & 18.8 \\
Geranium phaeum & $\ldots$ & $\ldots$ & 18.8 \\
Stachy sylvatica & $\ldots$ & $\ldots$ & 20.1 \\
Cardamine impatiens & $\ldots$ & $\ldots$ & 20.4 \\
Polystichum setiferum & $\ldots$ & $\ldots$ & 21.3 \\
Asplenium trichomanes & $\ldots$ & $\ldots$ & 26.8 \\
Veronica montana & $\ldots$ & $\ldots$ & 27.4 \\
Geranium robertianum & $\ldots$ & $\ldots$ & 27.5 \\
Sambucus nigra & $\ldots$ & $\ldots$ & 31.4 \\
Dryopteris filix-mas & $\ldots$ & $\ldots$ & 32.2 \\
Mycelis muralis & $\ldots$ & $\ldots$ & 33.3 \\
Stellaria media & $\ldots$ & $\ldots$ & 33.9 \\
Acer pseudoplatanus & $\ldots$ & $\ldots$ & 35.5 \\
Circaea lutetiana & $\ldots$ & $\ldots$ & 52.2 \\
Oxalis acetosella & $\ldots$ & $\ldots$ & 54.7 \\
Galeobdolon luteum s.l. & $\ldots$ & 14.7 & 59.8 \\
Totals & \multicolumn{3}{|c}{} \\
No. of plots & 135 & 135 & 135 \\
No. of diagnostic species & 48 & 20 & 41 \\
\hline Note Abbreviations: MOF: mixed-oak forests, BF: beech forests, RF: ravine forests. & & &
\end{tabular}

\section{Discussion AND Conclusions}

Studying the ecological conditions, vegetation pattern, and species composition of karst depressions may provide important information for the conservation and management of karst surfaces. Many studies in vegetation science have focused on the large-scale vegetation patterns of karst forms (e.g. Lausi, 1964; Bátori et al., 2009), but only relatively few studies deal with the fine-scale vegetation pattern of sinkholes and the use of transects to reveal them (e.g., Gargano et al., 2010). In our study, the species composition and vegetation pattern of solution sinkholes were analyzed in relation to sinkhole size in a subMediterranean woodland area of Hungary. The vegetation pattern of sinkholes can be summarized and the questions posed in the Introduction can be answered as follows.

(i) Vegetation inversion is a well known phenomenon in karst depressions (Beck v. Mannagetta, 1906; Lausi, 1964; Horvat, 1953; Favretto and Poldini, 1985). In Hungary, south-facing slopes receive much more solar radiation, and thus, are warmer than north-facing slopes (Jakucs, 1977). In smaller sinkholes of the study site, the vegetation pattern does not change substantially along the transects, and the slopes are floored
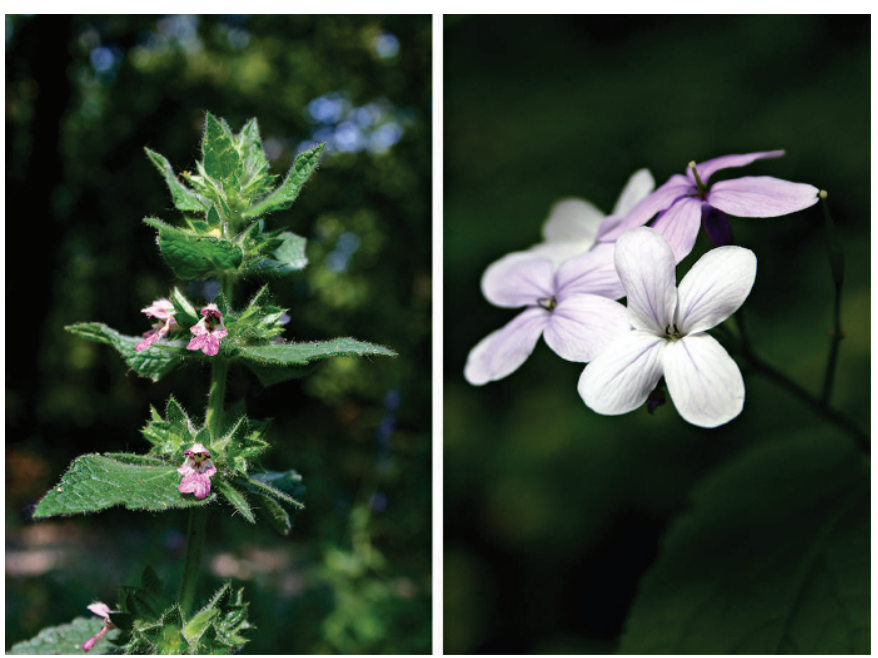

Figure 3. Stachys alpina (left), a glacial relict, and Lunaria rediviva (right), a mountain species, in the sinkholes of the Mecsek Mountains, southern Hungary.

by vegetation characteristic only of beech forests or mixed-oak forests. In contrast, south-facing slopes in larger sinkholes are dominated by mixed-oak forests or beech forests, north-facing slopes by beech forests, and the bottom of sinkholes by ravine forests. Vegetation inversion is well pronounced only in the largest sinkholes, where beech forest vegetation replaces that of mixed-oak forests on the deeper parts of the slopes. This phenomenon was also confirmed by field observations. Similar results were published by Bátori et al. $(2009,2011)$ in different scales.

(ii) Climate change has already produced and will continue to produce numerous shifts in the distributions of species (Walther et al., 2002), which highlights the role of current and potential refuge areas. A prominent finding in our study is that the low-lying sinkholes (250 to 500 masl) of the Mecsek Mountains provide good refuge areas for many species adapted to cool and moist habitats. This is a consequence of the morphologic characteristics of karst depressions, which strongly determine both abiotic (e.g., air humidity, air temperature, soil moisture) and biotic (e.g., vegetation pattern) parameters of sinkholes (see also, Geiger, 1950; Antonić et al., 1997; Bárány-Kevei, 1999; Antonić et al., 2001, Whiteman et al., 2004; Gargano et al., 2010). The extent of refuge areas shows a positive correlation with sinkhole size in the Mecsek Mountains. In general, the extent of cool and moist habitats in the sinkholes increases with sinkhole diameter, due to the fact that wider sinkholes are usually deeper.

(iii) Sinkholes of the Mecsek Mountains harbor many vascular plant species that are missing or are very rare in the surrounding habitats, and they can be considered habitat islands in the "ocean" of local 

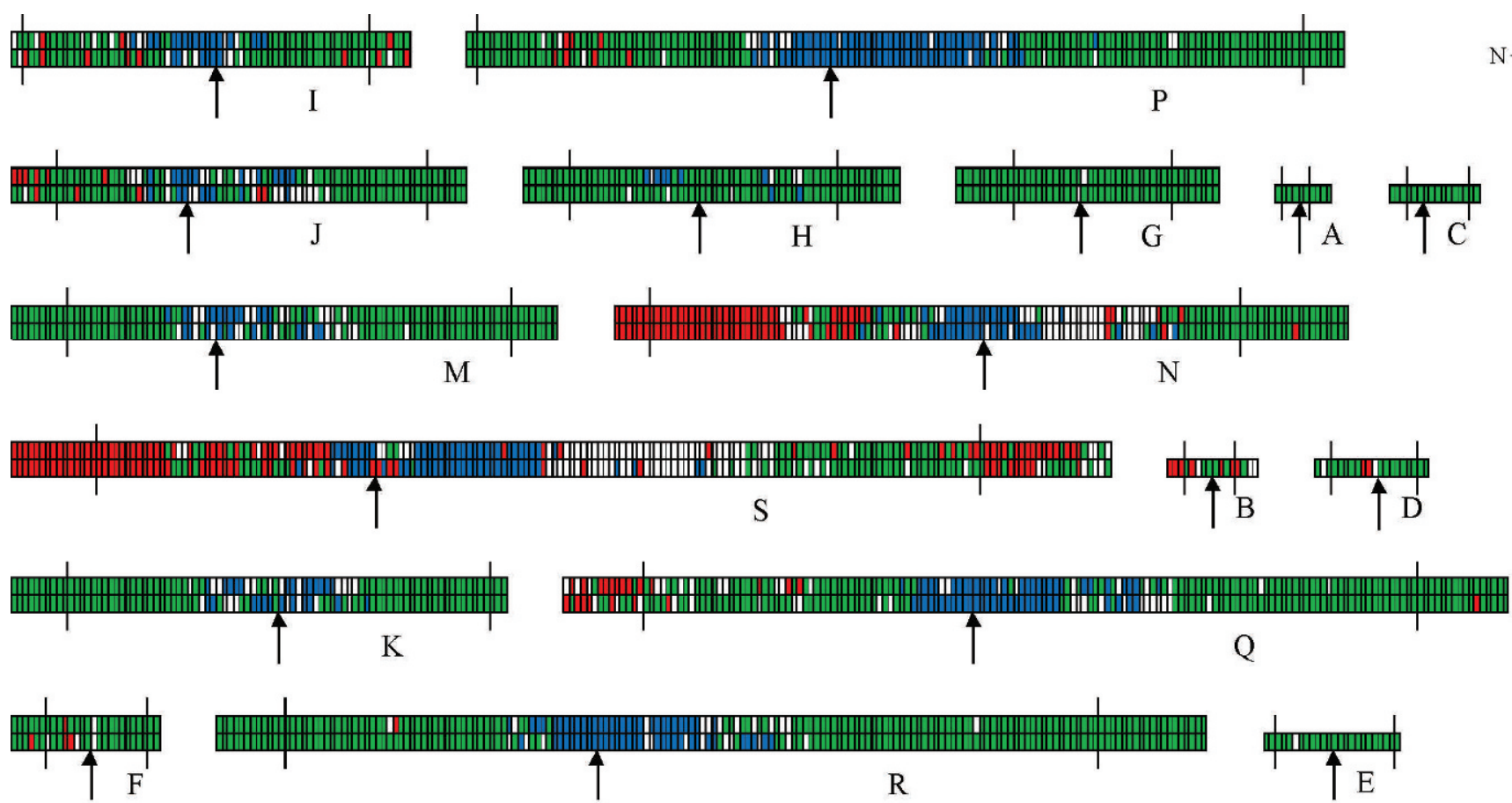

$\mathrm{K}$

Q
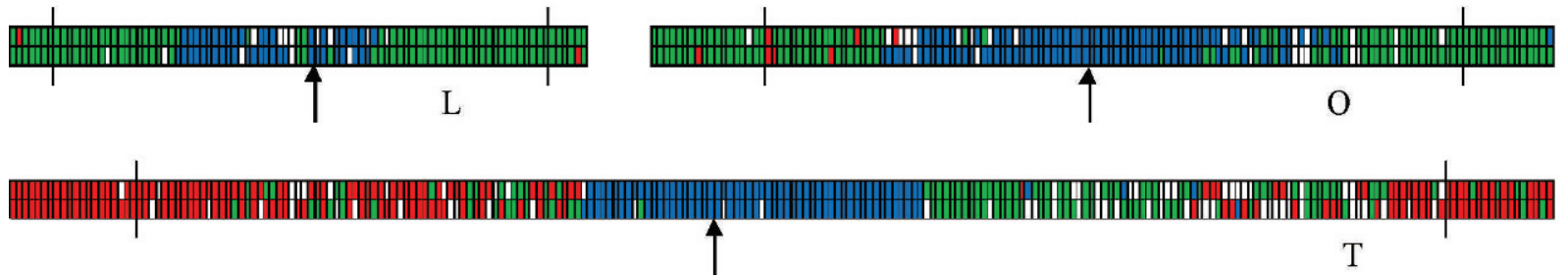

Figure 4. Plots in the north-south transects, with north to the left, that are dominated by mixed-oak forest (red), beech forest (green), or ravine forest (blue) species in the sinkholes (A-T) of the Mecsek Mountains. White plots are transitional or empty. Short vertical lines indicate where the slope falls below $10^{\circ}$ at the edges of the sinkholes, and arrows mark the deepest point of the sinkholes, where slope exposure changes.

Table 3. Total number of plant species and cool-adapted species of various types, as well as the number of plots dominated by ravine forest species for the sinkholes, which increase in size from $\mathrm{A}$ to $\mathrm{T}$.

\begin{tabular}{|c|c|c|c|c|c|c|c|c|c|c|c|c|c|c|c|c|c|c|c|c|}
\hline Sinkhole & A & B & $\mathrm{C}$ & $\mathrm{D}$ & $\mathrm{E}$ & $\mathrm{F}$ & G & $\mathrm{H}$ & I & $\mathrm{J}$ & $\mathrm{K}$ & $\mathrm{L}$ & M & $\mathrm{N}$ & $\mathrm{O}$ & $\mathrm{P}$ & Q & $\mathrm{R}$ & $\mathrm{S}$ & $\mathrm{T}$ \\
\hline $\begin{array}{l}\text { Total number } \\
\text { of plant }\end{array}$ & & & & & & & & & & & & & & & & & & & & \\
\hline species & 23 & 37 & 23 & 30 & 32 & 43 & 39 & 58 & 68 & 68 & 66 & 72 & 63 & 97 & 82 & 91 & 86 & 93 & 113 & 141 \\
\hline Glacial relicts & $\cdots$ & $\cdots$ & $\cdots$ & $\cdots$ & $\cdots$ & $\cdots$ & $\cdots$ & $\cdots$ & $\cdots$ & $\cdots$ & $\cdots$ & $\cdots$ & $\cdots$ & $\cdots$ & $\cdots$ & 1 & $\cdots$ & 1 & $\cdots$ & 1 \\
\hline $\begin{array}{l}\text { Mountain } \\
\text { species } \\
\text { Wet woodland }\end{array}$ & $\cdots$ & $\cdots$ & $\cdots$ & $\cdots$ & $\cdots$ & $\cdots$ & $\cdots$ & 1 & 2 & 1 & 2 & 2 & 2 & 3 & 2 & 3 & 3 & 5 & 3 & 6 \\
\hline $\begin{array}{l}\text { species } \\
\text { Other } \\
\text { diagnostic } \\
\text { species of the }\end{array}$ & $\ldots$ & $\ldots$ & $\ldots$ & $\ldots$ & $\ldots$ & $\ldots$ & $\ldots$ & 2 & 3 & 4 & 2 & 3 & 2 & 7 & 5 & 6 & 6 & 8 & 6 & 8 \\
\hline $\begin{array}{l}\text { ravine forests } \\
\text { Plots } \\
\text { dominated by } \\
\text { ravine forest }\end{array}$ & 4 & 3 & 2 & 2 & 4 & 8 & 7 & 11 & 12 & 11 & 10 & 11 & 12 & 16 & 15 & 13 & 16 & 16 & 16 & 18 \\
\hline species & $\ldots$ & $\ldots$ & $\ldots$ & $\ldots$ & $\ldots$ & $\ldots$ & $\ldots$ & 8 & 22 & 20 & 25 & 46 & 25 & 39 & 109 & 79 & 59 & 61 & 65 & 107 \\
\hline
\end{tabular}




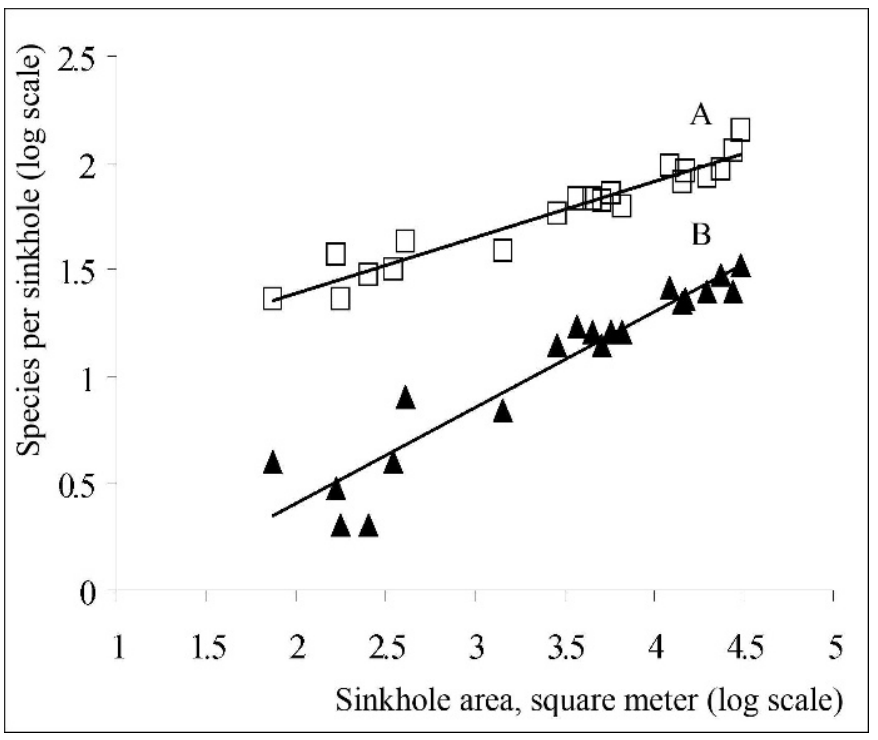

Figure 5. Relationship between sinkhole area (log $\log _{10}$ transformed) and species number ( $\log _{10}$ transformed) for vascular vegetation of the Mecsek Mountains $(N=20)$. Species-area lines were determined for all species (A: $y=0.2612 x+$ $0.8670, R^{2}=0.9302$ ) and the group of relict, mountain, wetwoodland species and other diagnostic species of the ravine forests (B: $\left.y=0.4465 x-0.4868, R^{2}=0.9006\right)$.

beech and mixed-oak forests. According to the wellknown species-area relationship (Arrhenius, 1921), species number is related to area by the function $S=$ $C A^{z}$, where $S$ is species number, $A$ is area of island, and $C$ and $z$ are positive constants. $C$ and $z$ constants were calculated by linear regression on the logarithmic form of the equation, $\log S=\log C+z \log A$, where $\log C$ represents the $y$-intercept and $z$ the slope. When all species of the studied sinkholes are considered, the $z$ value is 0.26 , which is in good agreement with the $z$ values received for many oceanic and habitat islands $(z=0.20$ to 0.35$)$ in island biogeography (MacArthur and Wilson, 1967; Simberloff and Abele, 1976; Begon et al., 2005). In contrast, when only the group of relict, mountain, wet-woodland species and other diagnostic species of the ravine forests is considered, the $z$ value is considerably higher $(z=0.45)$. According to Rockwood (2006), $z$ values larger than expected arise when islands have a large habitat diversity and are more or less isolated. For example, Culver et al. (1973) found a relatively high $z$ value for terrestrial invertebrates in caves $(z=0.72)$, Trejo-Torres and Ackerman (2001) for endemic orchid species on geologically diverse montane islands $(z=0.68)$, and Brown (1971) for small boreal mammals on isolated mountaintops $(z=0.43)$. Accordingly, our results suggest that the habitat topography of large sinkholes is complex and the extent of cool and moist habitats considerably increases with sinkhole size (Fig. 4), so larger sinkholes may preserve many more vascular plant species adapted to cool and moist habitats than smaller sinkholes.

Therefore, conservation management must focus on protecting habitats of larger sinkholes and their surroundings in the Mecsek Mountains. This management should include establishing a buffer zone around all sinkholes, in accordance with the proposal of the Forest Sinkhole Manual (Kiernan, 2002).

\section{ACKNOWLEDGMENTS}

We would like to thank András Vojtkó, Sándor Bartha and Tamás Morschhauser for useful comments and suggestions. This research was supported by the TÁMOP4.2.2/08/1/2008-0008 and the TÁMOP-4.2.1/B-09/1/KONV2010-0005 programs of the Hungarian National Development Agency.

\section{REFERENCES}

Ádám, L., Marosi, S., and Szilárd, J., eds., 1981, A Dunántúli-dombság (Dél-Dunántúl). Magyarország tájföldrajza 4: Budapest, Akadémiai Kiadó, 704 p.

Antonić, O., Kušan, V., and Hrašovec, B., 1997, Microclimatic and topoclimatic differences between the phytocoenoses in the Viljska Ponikva Sinkhole, Mt. Risnjak, Croatia: Hrvatski Meteorološki časopis, v. 32, p. 37-49.

Antonić, O., Hatic, D., and Pernar, R., 2001, DEM-based depth in sink as an environmental estimator: Ecological Modeling, v. 138, p. 247-254. doi:10.1016/S0304-3800(00)00405-1.

Arrhenius, O., 1921, Species and area: Journal of Ecology, v. 9, p. 95-99.

Bárány-Kevei, I., 1999, Microclimate of karstic dolines: Acta Climatologica Universitatis Szegediensis, v. 32-33, p. 19-27.

Bátori, Z., Gallé, R., Erdős, L., and Körmöczi, L., 2011, Ecological conditions, flora and vegetation of a large doline in the Mecsek Mountains (South Hungary): Acta Botanica Croatica, v. 70, p. 147-155. doi:10.2478/v10184-010-0018-1.

Bátori, Z., Csiky, J., Erdős, L., Morschhauser, T., Török, P., and Körmöczi, L., 2009, Vegetation of the dolines in Mecsek Mountains (South Hungary) in relation to the local plant communities: Acta Carsologica, v. 38, no. 2-3, p. 237-252.

Beck v. Mannagetta, G., 1906, Die Umkehrung der Pflanzenregionen in den Dolinen des Karstes: Sitzungsberichte der Kaiserliche Akademie der Wissenschaften in Wien-Mathematisch-Naturwissenschaftliche Klasse, v. 115, p. 3-20.

Begon, M., Townsend, C.R., and Harper, J.L., 2006, Ecology: From Individuals to Ecosystems: Oxford, Blackwell, 738 p.

Brown, J.H., 1971, Mammals on mountaintops: nonequilibrium insular biogeography: The American Naturalist, v. 105, no. 945, p. 467-478.

Brullo, S., and Giusso del Galdo, G., 2001, Astracantha dolinicola (Fabaceae), a new species from Crete: Nordic Journal of Botany, v. 21, p. 475-480. doi:10.1111/j.1756-1051.2001.tb00799.x.

Christiansen, K., and Bellinger, P., 1996, Cave Pseudosinella and Oncopodura new to science: Journal of Cave and Karst Studies, v. 58 , no. 1 , p. $38-53$.

Chytrý, M., Tichý, L., Holt, J., and Botta-Dukát, Z., 2002, Determination of diagnostic species with statistical fidelity measures: Journal of Vegetation Science, v. 13, no. 1, p. 79-90. doi:10.1111/j.1654-1103. 2002.tb02025.x.

Cowie, J., 2007, Climate Change: Biological and Human Aspects: New York, Cambridge University Press, 504 p.

Culver, D.C., Holsinger, J.R., and Baroody, R., 1973, Toward a predictive cave biogeography: the Greenbrier valley as a case study: Evolution, v. 27 , p. $689-695$. 
Culver, D.C., and Sket, B., 2000, Hotspots of subterranean biodiversity in caves and wells: Journal of Cave and Karst Studies, v. 62, no. 1, p. 11-17.

Dakskobler, I., Sinjur, I., Veber, I., and Zupan, B., 2008, Localities and sites of Pulsatilla vernalis in the Julian Alps: Hacquetia, v. 7, p. 47-69.

Egli, B.R., 1991, The special flora, ecological and edaphic conditions of dolines in the mountain of Crete: Botanica Chronika, v. 10, p. $325-335$.

Egli, B.R., Gerstberger, P., Greuter, W., and Risse, H., 1990, Horstrissea dolinicola, a new genus and species of umbels (Umbelliferae, Apiaceae) from Kriti (Greece): Willdenowia, v. 19, no. 2, p. 389-399.

Elliott, W.R., 2007, Zoogeography and biodiversity of Missouri caves and karst: Journal of Cave and Karst Studies, v. 69, no. 1, p. 135-162.

Favretto, D., and Poldini, L., 1985, The vegetation in the dolinas of the karst region near Trieste (Italy): Studia Geobotanica, v. 5, p. 5-18.

Gargano, D., Vecchio, G., and Bernardo, L., 2010, Plant-soil relationships in fragments of Mediterranean snow-beds: ecological and conservation implications: Plant Ecology, v. 207, no. 1, p. 175-189. doi:10.1007/ s11258-009-9663-7.

Geiger, R., 1950, Das Klima der bodennahen Luftschicht: Ein Lehrbuch der Mikroklimatologie, third edition: Braunschweig, Friedr. Vieweg \& Sohn, $460 \mathrm{p}$.

Habel, J.C., and Assmann, T., eds., 2010, Relict species: Phylogeography and Conservation Biology: Heidelberg, Springer, 449 p. doi:10.1007/ 978-3-540-92160-8.

Horvat, I., 1953, Vegetacija ponikava: Hrvatski Geografski Glasnik, v. $14-15$, p. $1-25$

Hoyk, E., 1999, Investigation of the vegetation and soil in the dolinas of Western Mecsek Mountains, South Hungary: Acta Carsologica, v. 28, no. 1, p. 105-113.

Iverson, L.R., and Prasad, A.M., 1998, Predicting abundance of 80 tree species following climate change in the Eastern United States: Ecological Monographs, v. 68, no. 4, p. 465-485. doi:10.1890/00129615(1998)068[0465:PAOTSF]2.0.CO;2.

Jakucs, L., 1977, A karsztok morfogenetikája: A karsztfejlődés varienciái: Budapest, Akadémiai Kiadó, 284 p.

Judson, M.L.I., 2007, A new and endangered species of the pseudoscorpion genus Lagynochthonius from a cave in Vietnam, with notes on chelal morphology and the composition of the Tyrannochthoniini (Arachnida, Chelonethi, Chthoniidae): Zootaxa, no. 1627, p. 53-68.

Kiernan, K., 2002, Forest Sinkhole Manual: Tasmania, Hobart, Forest Practices Board, $35 \mathrm{p}$.

Király, G., ed., 2009, Új Magyar Füvészkönyv. Magyarország hajtásos növényei. Határozókulcsok: Jósvafö, Aggteleki Nemzeti Park Igazgatóság, $616 \mathrm{p}$.

Köhn, J., and Waterstraat, A., 1990, Recent distribution of glacial relict Malacostraca in the lakes of Mecklenburg: Annales Zoologici Fennici, v. 27 , p. $237-240$.

Lausi, D., 1964, Vorläufiger Überblick über die Vegetation der Triester Karstdolinen: Acta Botanica Croatica, v. 4, p. 65-71.

Lazarević, P., Lazarević, M., Krivošej, Z., and Stevanović, V., 2009, On the distribution of Dracocephalum ruyschiana (Lamiaceae) in the Balkan Peninsula: Phytologia Balcanica, v. 15, no. 2, p. 175-179.

Lewis, J.J., and Bowman, T.E., 2010, The subterranean asellids of Maryland: Description of Caecidotea nordeni, new species, and new records of $C$. holsingeri and $C$. franzi (Crustacea: Malacostraca:
Isopoda): Journal of Cave and Karst Studies, v. 72, no. 2, p. 100-104. doi:10.4311/jcks20091sc0092.

Lovász, Gy., 1971, Adatok az Abaligeti-karszt geomorfológiai és hidrológiai jellemzéséhez: Földrajzi Értesítő, v. 20, p. 283-295.

MacArthur, R.H., and Wilson, E.O., 1967, The Theory of Island Biogeography: Princeton, Princeton University Press, 203 p.

Özkan, K., Gulsoy, S., Mert, A., Ozturk, M., and Muys, B., 2010, Plant distribution-altitude and landform relationships in karstic sinkholes of Mediterranean region of Turkey: Journal of Environmental Biology, v. 31 , p. $51-60$.

Pericin, C., and Hürlimann, H., 2001, Beobachtungen zur vertikalen Verteilung der Moosarten in der Doline Sterna-Filaria im Karstgebiet von Buje/Buie in Istrien (Kroatien): Bauhinia, v. 15, p. 91-96.

Rockwood, L.L., 2006, Introduction to Population Ecology: Oxford, Blackwell Scientific Publications, 339 p.

Sagarin, R.D., Barry, J.P., Gilman, S.E., and Baxter, C.H., 1999, Climaterelated change in an intertidal community over short and long time scales: Ecological Monographs, v. 69, no. 4, p. 465-490. doi:10.1890/ 0012-9615(1999)069[0465:CRCIAI]2.0.CO;2.

Schindler, D.W., Bayley, S.E., Parker, B.R., Beaty, K.G., Cruikshank, D.R., Fee, E.J., Schindler, E.U., and Stainton, M.P., 1996, The effects of climatic warming on the properties of boreal lakes and streams at the Experimental Lakes Area, northwestern Ontario: Limnology and Oceanography, v. 41, no. 5, p. 1004-1017.

Sheldon, T.A., Mandrak, N.E., and Lovejoy, N.R., 2008, Biogeography of the deepwater sculpin (Myoxocephalus thompsonii), a Nearctic glacial relict: Canadian Journal of Zoology, v. 86, p. 108-115. doi:10.1139/ Z07-125.

Simberloff, D.S., and Abele, L.G., 1976, Island biogeography theory and conservation practice: Science, v. 191 , no. 4224, p. 285-286. doi:10.1126/science.191.4224.285.

Simon, T., 2000, A magyarországi edényes flóra határozója: harasztok, virágos növények: Budapest, Nemzeti Tankönyvkiadó, 845 p.

Szmorad, F., 1999, Adatok az Aggteleki-karszt és a Galyaság flórájához I.: Kitaibelia, v. 4, no. 1, p. 77-82.

Tichý, L., 2002, JUICE, software for vegetation classification: Journal of Vegetation Science, v. 13, no. 3, p. 451-453. doi:10.1111/j.1654-1103. 2002.tb02069.x.

Trejo-Torres, J.C., and Ackerman, J.D., 2001, Biogeography of the Antilles based on a parsimony analysis of orchid distributions: Journal of Biogeography, v. 28, p. 775-794. doi:10.1046/j.13652699.2001.00576.x.

Vojtkó, A., 1997, Új adatok a Tornai-karszt flórájához és vegetációjához: Kitaibelia, v. 2, no. 2, p. 248-249.

Walther, G.-R., Post, E., Convey, P., Menzel, A., Parmesan, C., Beebee, T.J.C., Fromentin, J.-M., Hoegh-Guldberg, O., and Bairlein, F., 2002, Ecological responses to recent climate change: Nature, v. 416, p. 389-437. doi:10.1038/416389a.

Whiteman, C.D., Haiden, T., Pospichal, B., Eisenbach, S., and Steinacker, R., 2004, Minimum temperatures, diurnal temperature ranges, and temperature inversion in limestone sinkholes of different sizes and shapes: Journal of Applied Meteorology, v. 43, p. 1224-1236. doi:10.1175/1520-0450(2004)043<1224:MTDTRA > 2.0.CO;2.

Wolowski, K., 2003, Euglenophytes reported from karst sink-holes in the Malopolska Upland (Poland, Central Europe): Annales de Limnologie - International Journal of Limnology, v. 39, no. 4, p. 333-346. doi: $10.1051 / \mathrm{limn} / 2003027$. 